\title{
The Signing, Provisional Application, and Conclusion of Trade and Investment Agreements in the EU: The Case of CETA and Opinion 2/15
}

\author{
David KLEIMANN ${ }^{\star} \&$ Gesa KüBeK ${ }^{\star}$
}

\begin{abstract}
The 'Wallonian Saga' associated with the threat on behalf of the Wallonian regional government to block the signature of the Comprehensive Economic and Trade Agreement (CETA) in October 2016 has illustrated a number of structural weaknesses of the European Union as an external treaty-maker in the field of EU Common Commercial Policy. These weaknesses concern issues of both democratic representation and the effectiveness of EU multilevel governance. The legal question of competence that determines the Union's power to conclude external commercial treaties by itself or, in the alternative, jointly with the Member States has now been clarified by the CJEU in Opinion 2/15. Against this backdrop, this article examines and discusses the constitutional fundamentals of EU economic treaty-making. The article provides an explanatory account of the division and nature of treaty-making competences in the EU; outlines the distinct modalities and procedures that the conclusion of international treaties as 'EU-only' or 'mixed' require respectively; discusses the law and practice of the provisional application of international economic treaties by the EU; reviews legal avenues that enable the entry into force of a mixed agreement despite its rejection by an individual Member State; and gives an overview of the relevant CJEU case law and the Court's conclusions in Opinion 2/15. Normatively, we argue in favour of adjusting the scope of future EU trade and investment agreements to the realm of EU exclusive competences in order to remedy the functional deficiencies of EU treaty-making that were exposed in the 'CETA-drama'. At the same time, we emphasize the need for - and outline a path towards - a qualitative change in $E U$ and Member State institutional practice that fully employs the channels of vertical political participation in the Union's multilevel governance structures so as to strengthen the legitimacy of EU economic treaty-making.
\end{abstract}

* David Kleimann (PhD, MILE, LL.M) is a Consultant in the field of international and EU economic law. Email: david.kleimann@eui.eu. Gesa Kübek is a Research Assistant (Wissenschaftliche Mitarbeiterin) at the Law Faculty of the University of Passau. Email: gesa.kuebek@uni-passau.de. The authors would like to express their gratitude for helpful comments received from Marise Cremona, Petros Mavroidis, Bernard Hoekman, Robert Wolfe and the anonymous reviewer of this Journal. Opinions expressed here, as much as remaining errors, shall be attributed to the authors alone. An earlier version of this article was published as EUI Working Paper RSCAS 2016/58 in November 2016, http://cadmus.eui.eu/handle/ $1814 / 43948$.

Kleimann, David \& Kübek, Gesa, 'The Signing, Provisional Application, and Conclusion of Trade and Investment Agreements in the EU: The Case of CETA and Opinion 2/15'. Legal Issues of Economic Integration 45, no. 1 (2018): 13-46.

(C) 2018 Kluwer Law International BV, The Netherlands 


\section{INTRODUCTION}

This article examines and discusses the constitutional fundamentals of EU economic treaty-making in light of the Union's contemporary external economic agenda and the Lisbon Treaty reform of 2009. The core objective that motivates this exercise is the intention to advance further clarity over the evolution of the law and practice of EU trade and investment policy governance in the aftermath of its latest primary law reform. It is for this purpose that this article employs two highly complementary case studies, notably the process applying to the signing, provisional application, and conclusion of the Comprehensive Economic and Trade Agreement (CETA) as well as the Opinion 2/15 proceedings and the Court's decision.

On 1 August 2014, negotiations of a free trade agreement (FTA) between the EU and Canada, known as the CETA were completed. The signature, provisional application, and conclusion of CETA have sparked a fierce political debate across the Union and its Member States. At the centre of this debate stood the question whether the EU has the legal competence to conclude CETA as an 'EU-only' agreement, i.e. in participation of its own institutions alone. A negative answer would have implied the conclusion of CETA as a so-called 'mixed agreement'. Mixed agreements, in turn, require joint unanimous signing and ratification by the EU and the Member States in their own right. In practice, the conclusion of mixed agreements currently triggers the participation of at least thirty-eight national and regional parliaments in the EU.

In light of the considerable expansion of the scope of EU Common Commercial Policy (CCP) following the entry into force of the Lisbon Treaty, the European Commission emphasized that it legally viewed CETA as an 'EU-only' agreement. The Commission's plan to propose CETA as such was, however, vigorously opposed by the Member States represented in the Council. ${ }^{1}$ In 2014, a majority of national parliaments urged then EU Trade Commissioner Karel De Gucht to propose the conclusion of contemporary EU trade and investment treaties as mixed agreements as they feared that an 'EUonly' conclusion would compromise their legitimacy 'in view of the important role national parliaments have in the democratic decision making process in the EU'. ${ }^{2}$ On 5 July 2016, in the eleventh hour, the Commission caved in to

\footnotetext{
Council of the European Union, Outcome of the Council Meeting, at 3463rd Council Meeting Foreign Affairs Trade Issues 4 (Brussels 13 May 2016) http://data.consilium.europa.eu/doc/document/ST-87 37-2016-INIT/en/pdf (accessed 23 June 2017).

2 Tweede Kamer, Letter to Mr de Gucht in the Framework of the Political Dialogue: The Role of National Parliaments in Free Trade Agreements (Den Haag 25 Apr. 2014), http://www.ttip2014.eu/files/content/ docs/Full\%20documents/Letter_to_Mr_De_Gucht_-_role_of_national_parliaments_in_free_trade_a gree_181-238913.pdf (accessed 23 June 2017).
} 
mounting political pressure in the Council and proposed the signing, provisional application, and conclusion of CETA as a mixed agreement. The consequences of that decision were not long in coming: In October 2016, the regional parliament of Wallonia voted against the Belgian signature of CETA. Its approval is a legal prerequisite for the signature and ratification of commercial agreements under Belgian constitutional law. Notwithstanding the Belgian government's approval of CETA, the EU's treaty-making capacity therefore hinged upon the Wallonian veto. On 27 October 2016, in the nick of time, the Belgian government reached an agreement on the "conditions under which the federal State and the federated entities exercise their full authority to sign CETA', $^{3}$ which paved the way for the agreement's subsequent signature by Canada and the EU. ${ }^{4}$

With its decision in Opinion 2/15 on the Union's competence to conclude 'new generation' EU trade and investment agreements in May 2017, the Court of Justice of the European Union (CJEU) provided ultimate clarity as to which institutions may legitimately pursue the Union's external objectives in its commercial relations. ${ }^{5}$ As reflected by the inter-institutional political debate on the legal status of CETA as well as the subsequent Wallonian drama, the outcome of Opinion 2/15 has important implications for EU trade and investment policy formulation as well as the de jure legitimacy of multilevel economic governance in the European Union. In its 2/15 decision, the Court held that with the exception from provisions relating to portfolio investment and the contentious Investor-to-State-Dispute-Settlement mechanism (ISDS), all components of the agreement can be concluded by the EU alone and without the approval of the Member States in their own right. ${ }^{6}$ Opinion 2/15 therefore confirms the tectonic shifts of competence that the Lisbon Treaty has brought about in the area of EU CCP. Overall, as we argue below, the Court provided permissive guidelines as to how mixed treaty-making can be avoided through alternative design of EU trade and investment agreements. In doing so, Opinion 2/15 created the conditions for more effective, efficient, and politically legitimate EU external economic action.

It is our general enquiry over the legitimacy, efficiency, and effectiveness of EU CCP that informs the legal questions we raise and discuss in this article. The underlying purpose of this contribution is to emphasize the need for a more nuanced and

3 Déclaration du Royaume de Belgique relative aux conditions de pleins pouvoirs parl'Etat fédéral et les Entités fédérées pour la signature du CETA, http://liege.mpoc.be/doc/europe/-AECG-CETA/Belgique_Declarationpour-la-signature-du-CETA_27-oct-2016.pdf (accessed 23 June 2017).

4 European Commission, EU-Canada Summit: Newly Signed Trade Agreement Sets High Standards for Global Trade, http://europa.eu/rapid/press-release_IP-16-3581_en.htm (accessed 23 June 2017).

Opinion 2/15, The FTA with Singapore, ECLI:EU:C:2017:376 (2017).

Ibid., para. 305. 
constructive debate about the de jure legitimacy and quality of alternate democratic processes that apply to the signing, provisional application, and conclusion of twenty-first century trade and investment agreements in the EU. It is true that distinct modalities of treaty conclusion in the EU allocate different participatory rights among the political institutions of the Union and its Member States in the decision-making process. Yet, the difference between Member State parliamentary participation in the conclusion of 'EU-only' or, in the alternative, 'mixed' agreements is not a choice between involvement and exclusion. Rather, the procedures that apply to the conclusion of 'EU-only' and 'mixed' agreements provide for a qualitatively different involvement of Member State parliaments in the ratification process. In a mode of vertical integration in multilevel EU governance, parliamentary control rights at the national level shape the voting behaviour of Member States' governments in the Council during the making of 'EU-only' agreements. At the same time, the 'EU-only' procedure elevates the role of the European Parliament (EP), which holds a veto right, in the democratic process. The conclusion of mixed agreements, in contrast, requires the horizontal participation of Member States' political institutions. Mixed agreements endow all Member State parliaments with decision-making rights that can, under certain circumstances, resemble the veto right of the EP and thus result in an extremely cumbersome and lengthy political process that sets incentives for political paralysis.

Against this background, this article discusses and examines five related issues that are pertinent to the process and substance of the application and conclusion of contemporary trade and investment agreements in the EU. Section 2 builds the foundation for a discussion by providing for an explanatory account of the division and nature of treaty-making competences in the EU. Section 3 outlines the distinct modalities and procedures that the conclusion of international treaties as 'EU-only' or 'mixed' requires respectively. Section 4 examines the purpose, law, and practice of the provisional application of international treaties by the EU and embeds the Council decision on the provisional application of CETA into this context. Section 5 discusses the legal effects of a potential rejection of CETA by a Member State parliament and/or government and outlines two legal avenues that enable the entry into force of a mixed agreement despite its rejection by an individual Member State government. Section 6 analyses the implications for future EU trade and investment treaty-making in light of the Court's decision on Opinion 2/15. Section 7 concludes this article with an outline of EU CCP governance in 2020 that would, in our view, render external treaty-making more democratic, more effective, more efficient, and more reliable. We argue in favour of adjusting the scope of future EU trade and investment agreements to the realm of EU exclusive competences as clarified by the CJEU in order to 
remedy the functional deficiencies of EU treaty-making that were exposed in the 'CETA-drama'. At the same time, we emphasize the need for - and outline a path towards - a qualitative change in EU and Member State institutional practice that fully employs the channels of vertical political participation in the Union's multilevel governance structures and thereby strengthens the legitimacy of EU economic treaty-making in its substance beyond formal rights of political participation.

\section{2 'EU-ONLY' VS 'MIXED' TRADE AND INVESTMENT AGREEMENTS: A QUESTION OF COMPETENCE}

This aim of this section is to build a foundation for a more nuanced examination of constitutional questions surrounding the signature, provisional application, and conclusion of external economic agreements in the EU. Drawing upon the notional distinction between EU exclusive, shared, and Member State exclusive competences, we discuss three categories of EU external agreements, notably 'EU-only', 'mixed' agreements, and 'facultative' mixed/EU-only agreements.

\subsection{THE SCOPE OF ARTICLE 207 TFEU AND THE EU'S OTHER WISE IMPLIED EXCLUSIVE POWERS}

Legally, the decision as to whether an agreement is concluded as 'EU-only' or 'mixed' depends on the scope and nature of EU external treaty-making competences. If the EU holds an exclusive competence, the Member States are prevented from legislating internally and may not negotiate and enter into international commitments.

Exclusive competences are listed in Article 3(1) TFEU. This list includes the CCP - i.e. the EU external trade competence - which is codified in Article 206 and 207 TFEU. The scope of the CCP has been expanded in several treaty reforms over the last decades in adaptation to the requirements of the negotiation and conclusion of multilateral and bilateral trade and investment treaties as well as implementing legislation. The inclusion of services, trade related intellectual property rights, and foreign direct investment (FDI) in the scope of exclusive EU competence as a result of the 2009 Treaty of Lisbon was arguably intended to adjust the scope of CCP exclusivity to the content of contemporary EU trade policy in general and EU preferential trade and investment agreements with third countries in particular. 
Prior to the CJEU's decision in Opinion 2/15, the exact scope of Article 207 and the question whether the entire content of CETA falls under this legal basis, has been subject to much debate among legal scholars and practitioners. Generally speaking, the choice of legal basis, according to settled case law, 'must rest on objective factors (...), which include the aim and content of that measure' ${ }^{7}$ To facilitate the determination of the legal basis for measures which may touch upon the scope of more than one of the legal bases of the TFEU, the Court developed the 'centre of gravity' theory, which entails an 'aims-test' that determines the predominant purpose of the measure in question. The Court, in its earlier judgments, held that '[i]f [the] examination of a measure reveals that it pursues two aims or that it has two components and if one of those aims or components is identifiable as the main one, whereas the other is merely incidental, the measure must be founded on a single legal basis, namely, that required by the main or predominant aim or component'.

In application of the 'centre of gravity' theory post-Lisbon case law, the Court has held that ' $[\mathrm{a}]$ European Union act falls within the common commercial policy if it relates specifically to international trade in that it is essentially intended to promote, facilitate or govern trade and has direct and immediate effects on trade'. As we will further discuss in Section 6, the Court advanced a wide application of the 'immediate and direct effects on trade' criterion in Opinion 2/15, which enabled it to subsume a broader range of EU-Singapore FTA (EUSFTA) content under Article 207 TFEU than Advocate General Eleonor Sharpston.

Yet, some elements of the modern generation of EU trade and investment agreements still fall within the realm of EU shared competences (Article 4 (2) TFEU). This notion has inspired much of the inter-institutional legal conflict over EU treaty-making powers and the conclusion of CETA. It is important to note, in this regard, that the internal exercise of a shared competence on behalf of the Union may, under certain conditions, imply exclusive external EU competence. As such, parts of trade and investment agreements that correspond to uniform EU rules resulting from the internal exercise of shared competences may thus broaden the scope of EU exclusive treaty-making competences by implication and, in turn, narrow the substantive scope of treaty parts that require EU Member States to become independent parties to the agreement. We turn to the question of implied exclusive EU competences.

See for instance, Case C-130/10, Parliament v. Council, EU:C:2012:472 (2012), para. 42 or Case C-377/ 12, Commission v. Council, EU:C:2014:1903 (2014), para. 34.

8 Case C-377/12, Commission v. Council, supra n. 7, para. 34. See also Case C-155/07, Parliament v. Council, EU:C:2008:605 (2008) paras 34-37; Case C-300/89, Commission v. Council ('Titanium Dioxide'), EU: C:1991:244 (1991) paras 17-21; Case C-411/06, Commission v. Parliament and Council ('Shipments of Waste'), EU:C:2009:518 (2009) paras 45-47; Case C-130/10, Parliament v. Council, supra n. 7, paras 4345 . 
Article 3 (2) TFEU provides for three situations where ' $\mathrm{t}$ ] he Union shall also have [implied] exclusive competence for the conclusion of an international agreement'. First, the EU acts alone externally when an EU legislative act requires the Union to do so. The EU may, secondly, obtain implied exclusive powers to conclude international agreements when this is necessary for the exercise and achievement of the objectives of its otherwise internal competences. ${ }^{9}$ Finally, the Union may act alone externally where the exercise of national Member States' competence could affect common rules or alter their scope. ${ }^{10}$ In contrast to the remaining two conditions for implied exclusivity, this legal paradigm - the so-called ERTA doctrine as developed in the case law of the CJEU - requires that the EU exercises its competence in the policy area in question to a large extent. Yet, the Court has progressively developed a lenient interpretation of the ERTA test's 'largely covered' criterion. In its most recent decisions in Green Network and Opinion 3/ 15, the Court underlined that considerable Member State discretion in the implementation of EU legislation does not exclude findings of implied exclusivity. ${ }^{11}$

The Court's authoritative interpretation of the scope of a priori and implied exclusive competences in contrast to shared competences in Opinion 2/15 finally provided clarity over the status quo of EU commercial treaty-making power in the Lisbon era. Opinion 2/15 is thus concerned with the precise delineation of the scope of a priori and implied exclusive competences in contrast to shared competences. It is this very question, which stands at the beginning of the current legal, political, and broader public debate about the two alternative democratic processes that apply to the ratification of EU trade and investment agreements.

OPINION 2/I5: THE CRUX OF THE CASE

The Commission, in its preliminary questions to the Court in Opinion 2/15, asked the CJEU to clarify the scope of EU implied exclusive powers, in particular, and the legal status of EU trade and investment agreements that include provisions falling under shared EU competences, in general. In contrast to previous cases (e.g. in Opinion 1/94) the Commission does not only inquire whether it has the exclusive competence to conclude the international agreement in question alone. Instead, the

\footnotetext{
9 Opinion 1/76, Inland Waterways, EU:C:1977:63 (1977) paras 3-4 as clarified in in the 'Open Skies' judgments, in particular Case C-467/98, Commission v. Denmark, EU:C:2002:625 (2002) para. 56; in this respect, see also Opinion 1/03, Lugano Convention, EU:C:2006:81 (2006) para. 36.

10 Case 22/70, AERTA/ERTA, EU:C:1971:32 (1971) para. 17; as clarified in Opinion 1/03, supra n. 9, para. 116.

11 Case C-66/13, Green Network, EU:C:2014:2399, paras 41-49 and Opinion 3/15, The Marrakesh Treaty EU:C:2017:114, paras 126-128.
} 
Commission asked whether the Union possesses the 'requisite competence' to conclude the EUSFTA by itself. ${ }^{12}$

Indeed, in its written and oral submissions to the Court, the Commission questions whether the Member States ought to become parties to an EU trade and investment agreement, which partly falls within the ambit of shared EU competences that are not implicitly exclusive in the sense of Article 3(2) TFEU. In other words, the Commission argued that the Member States are not required to become parties to an agreement that covers non-exclusive shared competences; it is then left to the political discretion of the responsible EU institutions - here: the Council on proposal by the Commission - to allow the Member States to become parties to the agreement, or not. 'Mixity' of an EU trade and investment agreement, in this case, would not be mandatory but facultative. By inference, treaty disciplines that fall into areas of shared competence still permit an EU-only conclusion of the agreement. For the purposes of this article, it is sufficient to distinguish between three different categories of external agreements.

First, the content of an EU trade and investment agreement with third countries may fall within the scope of EU (a priori and implied) exclusive treaty-making powers in its entirety. The main question that arises here regards the exact scope of exclusivity. While the Commission and the EP frequently argue for a broader scope, the Member States tend to interpret the scope of exclusive EU competence narrowly. EU exclusivity of competences prevents Member States from acting in the respective policy area. The conclusion of the treaty as 'EU-only' is mandatory. ${ }^{13}$ The Member States must not become parties to the agreement.

Second, the conclusion of an agreement as 'mixed' is mandatory when a treaty, in addition to content covered by EU exclusive competence or shared competences, includes rules that fall within the exclusive competence of the Member States. In this case, the Member States must act as independent parties to the treaty in order to assume the legal obligations of the external agreement that are not covered by any EU competence. In Court, EU institutions and the Member States traditionally disagree as to whether certain treaty rules fall within the scope of exclusive Member States competences, or not.

A third and more contentious category concerns EU external agreements that cover rules, which fall under (a priori or implied) exclusive as well as shared EU competences without touching upon exclusive Member States

\footnotetext{
Opinion 2/15, Request for an Opinion Submitted by the European Commission Pursuant to Art. 218(11) TFEU, OJ C 363. 2015/C 363/22.

13 The EU may, however, for practical or political reasons, decide to delegate such treaty powers back to the MS. The 2012 Investment Regulation (Regulation No 1219/2012, O.J. 2012. L 351/40), to name one, grants the European Commission the right to authorize individual MS, upon request and on a caseby-case basis, to negotiate and conclude bilateral investment treaties with third countries.
} 
competences. As explained above, the procedure for EU treaty conclusion is, in this case, facultative. It has previously been argued that 'mixity' is mandatory as soon as only miniscule parts of an external agreement fall outside the scope of EU exclusive competence. ${ }^{14}$ This would imply that a single treaty provision that falls within the ambit of shared EU competences triggers mandatory Member States participation in the treaty conclusion and national ratification procedures in twenty-eight Member States in addition to the Commission, the Council, and the EP. This view, however, is unconvincing. As long as treaty content falls within the scope of EU treaty-making powers under Article 216 (1) TFEU, whether exclusive or non-exclusive, there is no discernible legal obligation to include Member States as independent parties to the agreement. ${ }^{15}$ However, there is no requirement that would prevent EU institutions from including Member States as parties to such an agreement either. As was recently argued by AG Wahl, 't]he choice between a mixed agreement or an EU-only agreement, when the subject matter of the agreement falls within an area of shared competence (...), is generally a matter for the discretion of the EU legislature ${ }^{16}$ - i.e. the Council on proposal of the Commission - subject to the procedural requirements of Article 218 TFEU.

\section{PROCEDURES: SIGNING AND CONCLUSION OF TRADE AND INVESTMENT AGREEMENTS IN THE EU}

Having provided an introduction to the nature of EU external economic competences and the substantive prerequisites for 'EU-only' and mixed agreements, we now turn to an examination of the procedural requirements for the signature and conclusion of both types of agreements respectively and briefly examine associated caveats. From a Member State's perspective, it may be useful to conceptualize the participatory rights and obligations accruing to them in the 'EU-only' democratic process as a vertical relationship with the mandated EU institutions, whereas all Member State governments stand, in

14 Wolfgang Weiß, Verfassungsprobleme des Abschlusses und der vorläufigen Anwendung des CETA Freihandelsabkommens mit Kanada, Stellungnahme zur Öffentlichen Anhörung des Ausschusses für Wirtschaft und Energie des Deutschen Bundestages 18 (Berlin 5 Sept. 2016), http://www.bundestag. de/blob/438052/9f45bd9ca1de30f51726df5d391b8702/stgn_weiss-data.pdf (accessed 23 June 2017).

15 The majority of academic literature appears to agree with this point. See for instance, Claus-Dieter Ehlermann, Mixed Agreements: A list of Problems, in Mixed Agreements 5 (D. O'Keeffe \& H.G. Schermers eds, Deventer: Kluwer Law and Taxation Publisher and Europa Instituut Leiden 1983); Joni Heliskoski, Mixed Agreements as a Technique for Organizing the International Relations of the European Community and Its Member States 36 et seq. (The Hague: Brill J Nijhoff 2001); Piet Eckhout, EU External Relations Law 211 et seq. (2d ed., Oxford: OUP 2011).

16 AG Wahl, Opinion 3/15, The Marrakesh Treaty EU:C:2016:657, para. 119. See also AG Sharpston, Opinion 2/15, The FTA with Singapore, para. 74. 
their own right, in a horizontal relationship with EU governing institutions in case of the 'mixed' procedural modus operandi.

\subsection{Signature AND CONCLUSION OF ‘EU-ONLY’ AGREEMENTS}

As explained above, 'EU-only' trade agreements are signed and concluded in sole participation of the Union's principal institutions - the Commission, the Council and the EP - without formally requiring national parliamentary approval as part of the ratification process. EU primary law prescribes that the Council adopts decisions both on the signing and the subsequent conclusion of trade agreements on the basis of proposals made by the Commission. ${ }^{17}$ The Council may choose to amend the proposals. Such an amendment, however, is subject to a unanimity requirement. ${ }^{18}$ The conclusion of a trade agreement (but not its signature ${ }^{19}$ ) further necessitates the consent of the EP. ${ }^{20}$ Assuming that the EP gives its consent for the conclusion, the proposals for both signature and conclusion can be adopted in the Council by qualified majority vote (QMV), notwithstanding policy-specific unanimity requirements spelled out in Article 207 TFEU and elsewhere in the treaties. ${ }^{21}$ From signature to conclusion of the respective treaty, the ratification period may only last a few months. 'EU-only' agreements, therefore, are likely to ensure a speedy entry into force of an agreement that has been negotiated over years. Legal certainty for governments, citizens, and businesses, a fast and predictable implementation of the agreement with a view to reaping commercial benefits, as well as the efficiency of the public decision-making process, are some of the advantages that the 'EU-only' ratification track carries with it.

Contrary to the views held by some commentators, the conclusion of 'EU only' agreements does anything but preclude national parliamentary participation in the ratification process. EU law does not prevent national governments from requesting or requiring a national parliamentary vote on an executive proposal to adopt an international agreement in the Council. Member State constitutions frequently contain provisions that allow for the parliamentary control rights or even render the respective votes mandatory. For instance, Germany's Chancellor Angela Merkel, one day in advance of the Commission's CETA proposals, clarified that ' $[t]$ he participatory rights of the German Bundestag allow that we, as the federal government, will, of course, involve the Bundestag. The parliamentary vote will play an important role in the German voting behaviour [in the Council] in Brussels' ${ }^{22}$ The

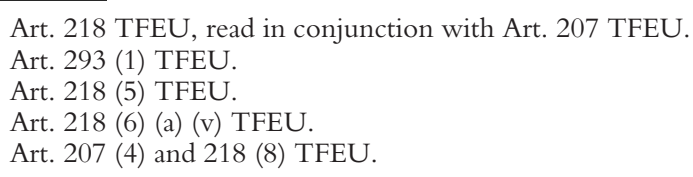


German Bundestag has indeed weighed in on the matter expeditiously and voted - with a majority of more than two thirds - in favour of a pertinent motion by the governing party factions. The motion demands that the German representative in the Council vote in favour of the EU signature and provisional application of CETA if the provisional application of the agreement does not encroach upon potential exclusive Member State competences. ${ }^{23}$ For the signing, provisional application, and conclusion of EU-only agreements, such modalities of national parliamentary participation may serve as an example par excellence.

At the EU level, the Lisbon Treaty of 2009 has greatly enhanced the participatory, information and control rights of the EP in the process of concluding CCP agreements with third countries. Most importantly, the EP is equipped with a right to veto international trade and investment agreements and receives regular reports on the progress of negotiations from the Commission. ${ }^{24}$ Members of the EP, and its Committee for International Trade (INTA), have made extensive use of the newly acquired rights and responsibilities throughout the past years. The EP is arguably most responsive to the political participation of European citizens in respect of CCP issues and is characterized by great proximity to the policy-making processes. These two factors alone may - over time - render the EP the best-suited EU institution to provide EU trade agreement ratification procedures with the necessary democratic legitimacy in accordance with the high standards of EP democracies. For EU-only agreements, in any case, it is the EP that is de jure responsible for guaranteeing democratic control and legitimacy.

\subsection{SigNATURE AND CONCLUSION OF 'MIXED’ AGREEMENTS IN THE EU}

Procedurally, the conclusion of a mixed agreement requires two parallel ratification processes that are of paramount significance. Ratification by both EU and Member State institutions does justice to the fact that both the EU and the Member States become parties to the treaty under international law in their own right. On the EUside, the above-mentioned procedures for the signature and conclusion of trade and investment agreements apply. In addition, in case of a mixed treaty, the agreement ought to be ratified by each Member State in accordance with its own national constitutional requirements. At the time of writing, the constitutions of the EU-28 prescribe, in sum, affirmative votes by at least thirty-eight national and regional

\footnotetext{
22 Deutsche Bundesregierung, Freihandelsabkommen CETA. Merkel: Bundestag muss mitstimmen, https:// www.bundesregierung.de/Content/DE/Artikel/2016/06/2016-06-29-merkel-will-bei-ceta-bundes tag-mitreden-lassen.html (accessed 23 June 2017).

23 Deutscher Bundestag, Antrag der Fraktionen der CDU/CSU und SPD, Drucksache 18/9663 (Berlin 20 Sept. 2016), http://dip21.bundestag.de/dip21/btd/18/096/1809663.pdf (accessed 23 June 2017).

24 Art. 207 (3) TFEU in conjuncture with Art. 218 (6) TFEU.
} 
parliaments. Some Member States may even require national referenda. Mixed agreements hence significantly prolong the duration of the ratification process that starts with the signature and ends with the entry into force of an agreement. ${ }^{25}$ Given the time necessary to acquire the consent of all chambers and notification thereof by all governments, the ratification of mixed agreements causes a great amount of legal uncertainty for both governments and businesses in the EU and for EU treaty partners. Ratification of the EU FTA with Korea (KOREU), for instance, took no less than five years. ${ }^{26}$ The conclusion of an 'EU-only' agreement in contrast, as noted above, may only take a few months.

The answer to the question of whether a treaty's content qualifies as 'EU-only' or 'mixed' thus has important implications for the efficiency and effectiveness of public decision-making in the EU system of multilevel governance and the procedures that are employed to endow the conclusion of the treaty with democratic legitimacy - in addition to the approval through elected governments represented in the Council. 'Efficiency and effectiveness of governance', in case of 'EU-only' treaties, however, does not implicate a trade-off with the value of 'democratic legitimacy'. We have noted above that Member State parliaments may well - and should indeed - play an important role in the national deliberation process that determines a Member State's vote in the Council, in accordance with participatory rights granted to a national parliament under the constitution of the respective Member State. Moreover, the central role of the EP in the process of concluding EU trade and investment agreements gives justice to the inherently collective nature of the EU's external trade and investment policy and the need for a common democratic process that legitimizes and exercises control over policy-formulation in the area of the Union's CCP.

Arguments in favour or against 'efficiency of governance' as well as vertical vs horizontal modes of parliamentary participation in multilevel governance decisionmaking reflect individual normative preferences and political interest configurations. Respective public or inter-institutional debates, however, need to be separated from a positive legal analysis of how EU Member States have decided to answer these questions in the EU treaties and Member States' constitutions. Legitimacy, above all, can only be derived from a democratic process that abides by the rule of the law, which is codified in the EU Treaties and Member State constitutions. To settle

$25 \quad$ To name but one example: The EEC-San Marino Agreement on Cooperation and Customs took eleven years to enter into force (OJ L 84/43). It was signed in 1991 and concluded in 2002 (Council Decision 2002/245/EC, OJ L 84/41 of 28/03/2002). See Alan Rosas, Mixed Union-Mixed Agreements, in International Law Aspects of the EU 125, 134 (Martti Koskenniemi ed., The Hague: Kluwer Law International 1998).

26 Council of the European Union, EU-South Korea Free Trade Agreement Concluded, Press Release 691/15 (Brussels 1 Oct. 2015), http://www.consilium.europa.eu/en/press/press-releases/2015/10/01-koreafree-trade/ (accessed 23 June 2017). 
respective political differences over the question of the appropriate applicable procedure for the conclusion of CETA and EU trade and investment agreements in general, we ought to return to the legal question of whether or not the Member States have conferred treaty-making powers to the Union that are sufficient for an 'EU-only' conclusion of twenty-first century trade agreements. The ongoing legal and scholarly debate on this issue - as well as the political positions of different institutions - can offer important insights. In the end, however, only the CJEU can decide upon such matters authoritatively and has done so in its Opinion 2/15 decision in May 2017, which we outline and discuss briefly in Section 6.

\section{PROVISIONAL APPLICATION: EU PRACTICE, TERMINATION, AND THE COUNCIL DECISION ON CETA}

This section examines a cornerstone of EU treaty application practice, which is of crucial importance for EU external relations conduct where the conclusion of mixed agreements would otherwise considerably delay the application of the respective treaty. It is for this reason that the provisional application of external treaties has become a commonplace and indispensible instrument of EU external relations. At the same time, the scope of EU competences vis-à-vis its Member States as well as the scope of the Union power - in time and substance - to apply treaties provisionally without acting ultra vires has been subject to intensive scrutiny and declaratory precautions on behalf of the Member States. This section serves to identify the relevant legal questions, outline past EU practice, and discuss - against this background - the Council decision on the provisional application of CETA. Finally, this section debunks a myth over the legal requirements for the termination of provisional application in the EU.

The provisional application of international agreements is vaguely regulated in Article 25 of the Vienna Convention of the Law of the Treaties (VCLT) of 1969, which codifies longstanding international legal customs. ${ }^{27}$ Provisional application describes a situation where the governments of the states that sign an international agreement decide to give effect to the rights and obligations of the said agreement as a whole or in part, upon signature or on an agreed date, pending the entry into force of the treaty. Hence, provisional application covers the time period between the signature of a treaty and its entry into force.

27 Art. 25 VCLT: 1 . 'A treaty or a part of a treaty is applied provisionally pending its entry into force if: (a) The treaty itself so provides; or (b) The negotiating States have in some other manner so agreed. 2. Unless the treaty otherwise provides or the negotiating States have otherwise agreed, the provisional application of a treaty or a part of a treaty with respect to a State shall be terminated if that State notifies the other States between which the treaty is being applied provisionally of its intention not to become a party to the treaty.' See also Vienna Convention on the Law of Treaties - A Commentary 407-421 (Oliver Dörr \& Kerstin Schmalenbach eds, Heidelberg: Springer 2012). 
Provisional treaty application has been an effective instrument in the context of mixed agreements where national parliamentary participation substantially prolongs the ratification process. The effectiveness of EU external action, and the effectiveness of international relations more generally, hinge significantly upon the provisional application of international treaties. ${ }^{28}$ Yet, despite the heavy reliance by the international community on this tool of customary legal practice, it remains a legal instrument of choice: neither EU law nor international law provide for any obligation to apply intergovernmental agreements provisionally before ratification procedures have been completed.

The VCLT provides that the 'negotiating States' may agree to apply a treaty, in view of pending ratification procedures, provisionally in its entirety or in part. As such, Article 25 VCLT ought to be understood to recognize and codify an executive prerogative of nation states' governments to apply international treaties upon or after signature until their entry into force. Given the circumstance that neither the European Community nor its successor, the European Union, can formally be regarded as a 'State' under the VCLT it remained unclear, for a long time, whether the Community had the powers to apply external treaties provisionally. It was only with the EC treaty reform of Amsterdam in 1997 that the Member States delegated a power of provisional application to the Community institutions, which is now legitimately considered to form part of customary international law. ${ }^{29}$

Up until to date, the EU treaties still give little guidance as to the permissible substantive scope, duration - or conditions for the end of - provisional treaty application. Article 218 (5) TFEU stipulates that 'the Council, on a proposal by the negotiator, shall adopt a decision authorizing the signing of the agreement and, if necessary, its provisional application before entry into force'. ${ }^{30}$

\subsection{Past EU practice}

Past EU practice has reflected a broad and permissive interpretation of Article 218 (5) TFEU on behalf of the Commission and the Member States represented in the Council. The ('mixed') EU-Korea FTA serves as an example par excellence. The EU

$28 \quad$ The likely most prominent example of the provisional application of a trade agreement is the 1947 General Agreement on Tariffs and Trade (GATT). In fact, the 1947 GATT was applied provisionally until the foundation of the World Trade Organisation in 1995 (30 Oct. 1947, UNTS 55 (1950), 308. Protocol of Provisional Application of the General Agreement on Tariffs and Trade (PPA)) The PPA was drafted to bring GATT provisions into effect whilst negotiations over the establishment of an ITO were on-going. Eight GATT contracting parties signed the PPA on 30 Oct. 1947, with the remaining fifteen original contracting parties agreeing soon thereafter. Art. 228 (2) of the Treaty of Rome did not include a respective provision. The Treaty of Amsterdam
replaced Art. 228 (2) by Art. 300 (2) TEC, which introduces the power of provisional treaty application for the Community institutions. Art. 218 (5) TFEU now contains revised wording.

30 Art. 218(5) TFEU. 
ratification period, as noted above, lasted no less than five years, whilst the parties provisionally applied the agreement six months after its signature. The Commission initially proposed to provisionally apply the agreement in its entirety. ${ }^{31}$ The Council decision, however, excluded two miniscule parts of the treaty, notably provisions relating to the criminal enforcement of intellectual property rights and cultural cooperation, which, according to some Member States, touched upon exclusive Member State competences. ${ }^{32}$

It is important to note, however, that the Council decision did not exclude other provisions that fall within the scope of competence areas that were now contested in Opinion 2/15, such as portfolio investment, ${ }^{33}$ or maritime transport services. ${ }^{34}$ In the proceedings, several Member States argued that maritime transport made for a shared competence whereas portfolio investment remained an exclusive Member State competence. ${ }^{35}$ Yet, the delegation of the power to provisionally apply EU external agreements as foreseen in the Council decision 'does not prejudge the allocation of competences between the Union and its Member States in accordance with the Treaties' ${ }^{36}$ It remains noteworthy, however, that the Council appeared to be of the legal opinion, reflected in its decision on the provisional application of the EU-Korea FTA, that it is empowered to apply treaty parts provisionally, which, according to the views expressed by the Member States in the Opinion 2/15 proceedings, fall outside of the scope of EU exclusive competences (such as maritime transport) or even fall within the scope of Member States exclusive competence (e.g. portfolio investment).

In sum, Member States have, in past practice, evidently supported and enabled the provisional application of treaty parts, which they otherwise consider to fall within the scope of shared or exclusive Member State competences. This fact seems to underline the nature of provisional application as an international legal instrument, which is distinct from EU treaty conclusion. Decisions of the Council under Article 218 (5) TFEU, in accordance with EU law and practice, may give effect to any substantive treaty provision.

Some legal scholars and practitioners have argued, however, that EU institutions act ultra vires if they give provisional effect to parts of trade

\footnotetext{
31 European Commission, Proposal for a Council Decision Authorising the Signature and Provisional Application of the Free Trade Agreement Between the European Union and Its Member States and the Republic of Korea, $\operatorname{COM}(2010) 136$ final.

32 Council Decision of 16 September 2010 on the signing, on behalf of the European Union, and provisional application of the Free Trade Agreement between the European Union and its Member States, of the One Part, and the Republic of Korea, of the other part, O.J. 2011, L 127. 2011/265/EU.

33 Art. 8.2 (2) (c) EU-Korea FTA.

34 Art. 7.47 EU-Korea FTA.

David Kleimann \& Gesa Kübek, The Future of EU External Trade Policy-Opinion 2/15: Report from the Hearing, EU Law Analysis Blog (4 Oct. 2016).

36 Council Decision of 16 Sept. 2010, supra n. 32, Recital (9).
} 
agreements that fall within the exclusive scope of Member States' competences or even competences shared with the Union. ${ }^{37}$ This argument stands at odds with consistent Member State practice in the Council as well as the provisions of EU primary law. The Council may decide to limit the scope of provisional application proposed by the Commission as it deems fit by amending the Commission proposal unanimously. Moreover, as noted above, Council decisions on a treaty's provisional application frequently entail disclaimers stipulating that such legal acts do not reflect the division of competences as between the EU and the Member States. The inclusion of treaty content falling under shared competences is thus entirely unproblematic. Yet, the inclusion of issues which fall within exclusive Member State competence, however, require a reference to Article 352(1) TFEU to complement the procedural legal basis of Article 218(5) TFEU with a substantive legal basis. In accordance with the rules specified in the Article 352 (1) TFEU, unanimous Council voting and mandatory EP consent would be required to adopt the respective decision.

Article 218 (5) TFEU does not attribute - in the decision as to whether and to what extent a treaty may be given effect on a provisional basis - any role to the EP. In post-Lisbon practice, however, the EP has been informally granted the right to give formal consent to EU trade agreements before an agreement is applied. The modality to achieve this end was, so far, to coordinate the date of provisional application, as decided by the Council, with the voting schedule of the EP. The EU-Korea FTA set an important precedent in this regard. With respect to CETA, EU Trade Commissioner Malmström has similarly assured the EP that the agreement 'will not be applied until after the EP has voted on it'. ${ }^{38}$ This practice is set to continue when and if contemporary EU trade and investment agreements are signed and concluded as 'EU-only' agreements in the future. Among EU institutions and the Member States, we find a broad consensus on the view that EP consent prior to provisional application of a treaty provides necessary democratic anchor to executive decision-making at the EU level that affects the livelihoods of European citizens. Respective intra- and inter-institutional discussions, at this point in time, aim at clarifying whether such practice could be formalized and required by including a respective provision on the necessity of EP consent prior to provisional application in the Council decisions on the signature and provisional application of the future respective treaties.

\footnotetext{
37 Foodwatch e.V., CETA durch die Hintertür: Wirtschaftsminister Gabriel Plant Entmachtung des Bundestages, http://www.foodwatch.org/de/presse/pressemitteilungen/ceta-durch-die-hintertuer-wirtschaftsmin ister-gabriel-plant-entmachtung-des-bundestages/ (accessed 23 June 2017).

38 European Parliament, Parliamentary Questions: Answer Given by Ms Malmström on Behalf of the Commission, P-004200/2016, (Brussels/Strasbourg 18 July 2016), http://www.europarl.europa.eu/si des/getAllAnswers.do?reference=P-2016-004200\&language=EN, (accessed 23 June 2017).
} 


\subsection{Terminating CETA provisional application (in Berlin?)}

Prior to the signature of CETA on 28 October 2016, the German Federal Constitutional Court (Bundesverfassungsgericht (BVerfG)) adopted a decision that encouraged the German government to ensure that 'it has, as a final resort, the possibility of terminating the provisional application of the Agreement for the Federal Republic of Germany by means of written notification'. ${ }^{39}$ On the occasion of the adoption by the Council of the decision authorizing the signing of CETA, Germany, Austria and Poland declared - in two separate statements - that 'as Parties to CETA they can exercise their rights which derive from Article 30.7(3)(c) of CETA. The necessary steps will be taken in accordance with EU procedures'. ${ }^{40}$

However, it is questionable, to say the least, whether an individual Member State can in fact terminate the provisional application of CETA unilaterally. It is true, to begin with, that all Member States act as independent contracting parties to CETA. The BVerfG therefore seems to believe that Germany, as a party to the agreement, has the right to unilaterally terminate the provisional application of the agreement. Neither the BVerfG, nor the German, Austrian or Polish representative, however, elaborated on the question of how an individual Member State could single-handedly terminate the provisional application of a treaty that is applicable to the Union in its entirety via a legal act adopted by the Council.

There are two ways to think about the Germano-Austrian and Polish positions: First, it may presume the right of full or partial termination of the provisional application of CETA on the territory of that respective Member State only. In the alternative, it may presume that a Member State has the right to terminate the provisional application of CETA on behalf of the EU and the remaining Member States.

The BVerfG guideline for the German government, first, seems to suggest that each Member State remains competent to terminate the application of CETA in its own territory vis-à-vis the EU, Canada and the remaining Member States. As a member of the EU's single market and customs union, it is, however, technically impossible for a Member State to unilaterally terminate the application of CETA in its territory without terminating the provisional application of the treaty in its entirety for all contracting

39 Press Release No. 71/2016 of 13 Oct. 2016, Applications for a Preliminary Injunction in the 'CETA' Proceedings Unsuccessful, 2 BvR 1368/16, 2 BvR 1444/16, 2 BvR 1823/16, 2 BvR 1482/16, 2 BvE 3/ 16, para. 3 cc http://www.bundesverfassungsgericht.de/SharedDocs/Pressemitteilungen/EN/2016/ bvg16-071.html (accessed 23 June 2017). See also Karsten Nowrot und Christian Tietje, CETA an der Leine des Bundesverfassungsgerichts: Zum schmalen Grat zwischen Ultra-vires-Kontrolle und Ultra-vires-Handeln EuR 137 (2017).

40 Council of the European Union, Comprehensive Economic and Trade Agreement (CETA) Between Canada, of the One Part, and the European Union and Its Member States, of the Other Part, Statements to the Council minutes (13463/1/16 Rev 1) Brussels (27 Oct. 2016) statements 21-22, http://data.consilium.europa. $\mathrm{eu} / \mathrm{doc} / \mathrm{document} / \mathrm{ST}-13463-2016-\mathrm{REV}-1 / \mathrm{en} / \mathrm{pdf}$ (accessed 23 June 2017). The quote refers to statement 21 by Germany and Austria. 
parties. CETA does allow for a partial provisional application through mutual consultation between the parties prior to the date of provisional application (Article 30.7 (b) CETA). A partial termination of the agreement's application by one contracting party, at a later stage, is not foreseen in CETA. According to the text of the agreement, the signing Member States may therefore not unilaterally terminate the provisional application of CETA in their respective territories, irrespective of whether such exemptions would be technically feasible or not.

In the alternative, does the BVerfG indicate that a single Member State, by acting as an independent party to the agreement may terminate the provisional application of CETA on behalf of the EU and all remaining Member States? As stated above, it is the Council that decides on the provisional application of a treaty following on a proposal by the Commission. Article 218 (9) TFEU stipulates that the decision to suspend the application of an agreement shall be proposed by the Commission and then adopted by the Council. Hence, the decision to end the provisional application of an agreement under EU law cannot be adopted by an individual Member State alone. Instead, the suspension, and, likewise, termination of an agreement's (provisional) application has to mirror the required voting rules for treaty adoption in the Council. For the majority of agreements that implies EU decision-making by QMV. As a result, the decision to terminate the provisional application of an agreement ought to be taken by the Union in accordance with Article 218 (9) TFEU - and not by individual Member States.

\subsection{Provisional application of CETA: The Council deCision}

The EP's approval of CETA on 15 February 2017, paved the way to apply the vast majority of CETA rules provisionally. ${ }^{41}$ The Council decision on the provisional application of CETA, as adopted on 28 October $2016,{ }^{42}$ reflects an intricate legal - political compromise among the Member States, which was negotiated under the impression of legal uncertainty in anticipation of the Opinion 2/15 CJEU decision. The Commission formally proposed the provisional application of CETA in its entirety. ${ }^{43}$ The CETA text itself explicitly provides for either full or partial provisional application of its provisions. ${ }^{44}$ After intensive discussion in the Council's Trade Policy Committee

41 European Commission, European Commission Welcomes Parliament's Support of Trade Deal with Canada, Press Release (2017) http://trade.ec.europa.eu/doclib/press/index.cfm?id=1624 (accessed 23 June 2017).

42 Council Decision (10974/16), Provisional Application of the Comprehensive Economic and Trade Agreement (CETA) Between Canada, of the One Part, and the European Union and Its Member States, of the Other Part (2016) http://data.consilium.europa.eu/doc/document/ST-10974-2016-INIT/en/pdf (accessed 23 June 2017).

43 European Commission, Proposal for a Council Decision on the Provisional Application of CETA, COM (2016) 470 final.. 
(TPC) on 15 July 2016, the Commission agreed with the Member States on the exclusion of certain parts of CETA from provisional application. ${ }^{45}$

The substance of the Council decision is characterized by both an attempt to maximize the scope of partial application of the agreement, on the one hand, and the Council's reluctance to apply CETA provisions provisionally that could - pending the CJEU's judgment in Opinion 2/15 at the time - fall within the ambit of Member States' competences. This observation indicates that Member States, contrary to some past practice, move towards more nuanced employment of the instrument in order to limit its scope to treaty parts falling under EU exclusive and shared competences. In addition to the legal uncertainty over the division of competences at the time the decision was adopted, the decision appears to reflect great Member States caution in regard of CETA provisions that are politically contentious.

The decision, first, excludes all investment protection disciplines from provisional application. Secondly, CETA's provisional application carves out the Investment Court System. Third, the Council shied away from including portfolio investment liberalization in the scope of provisional application. The decision hence provides for an application of CETA investment liberalization provisions 'only in so far as foreign direct investment is concerned'. ${ }^{46}$ Moreover, the financial services chapter of CETA (Chapter 13) 'shall not be provisionally applied in so far as [it] concern[s] portfolio investment, protection of investment or the resolution of investment disputes between investors and states'. ${ }^{47}$ In contrast, the Council decision provides for the application of CETA's sustainable development chapters (Chapters 22-24), which 'shall respect the allocation of competences between the EU and the Member States', ${ }^{48}$ and provisions on moral rights protection in the agreement's Intellectual Property Rights (IPR) chapter. Other legally contentious policy areas, such as the agreement's transport services disciplines as well as the mutual recognition of professional qualifications will also be applied provisionally. With the exception of substantive disciplines governing FDI protection, the carve outs from CETA's provisional application therefore seemingly mirror the Court's decision in Opinion 2/15, which solely excluded portfolio investment and ISDS from the scope of the EU's exclusive competence. The shared nature of EU competence for portfolio investment and ISDS, however, give much room for

$44 \quad$ Art. 30.7(3)(a), (b) CETA

45 [Unofficial] European Commission: Notes on the Meeting of the Trade Policy Committee (members) (15 July 2016), http://www.politico.eu/wp-content/uploads/2016/08/Notes-TPC-July-15.pdf (accessed 23 June 2017).

46 Council of the European Union, Council Decision on the Provisional Application of CETA, supra n. 43, Art. 1 (1) (a).

$47 \quad$ Ibid., Art. 1(1) (b).

48 Ibid., Art. 1 (1) (d). 
political discretion to the EU institutions as regards the provisional application of future EU trade and investment agreements.

As much as the decision of the Council marks a legal-political compromise that will give effect to the overwhelming majority of CETA rules and provisions, it also raises questions about the implementation of the agreement. Contemporary EU trade agreements employ a broad asset-based definition of 'investment' that covers both FDI and portfolio investment obligations. In the practice of the design of EU external economic agreements, it is technically challenging to separate foreign direct from portfolio investments, given such a broad asset based definition of investment - unless future trade agreements were to exclude investment policy provisions in their entirety. A separation of investment protection rules from liberalization disciplines would cause much less of a technical problem for the design of EU external agreements. The Council decision of 27 October 2016, clarifies, however, that the application of CETA must distinguish between foreign direct and portfolio investment liberalization and exclude the latter from implementation prior to the entry into force of the agreement. The decision, however, remains remarkably silent on how this separation should be conducted in commercial practice and thus defers decisions about the technical implementation of this political choice to the EU executive arm - the European Commission.

\section{CETA 'WALLONAISE': WHAT HAPPENS IF ...}

The mixed conclusion of CETA enables the Member States, as independent contracting parties, to subject the agreement to national constitutional treatymaking procedures. Does this fact imply that an individual Member State can veto the signing and conclusion of the entire agreement? This question was raised by Advocate General Sharpston at the very end of the oral proceedings in Opinion 2/15. In this section, we examine the legal implications of a Member States' refusal to sign or ratify CETA. First, we scrutinize the immediate legal effect of a national parliamentary 'no'. Operating under the assumption that a state government decides to follow a negative parliamentary vote, the second part of the section addresses the scope and impact of a potential national executive rejection for the signature and ratification of CETA. In particular, we question whether a Member State, in the context of a mixed agreement, can de jure reject a treaty's application in areas of EU exclusive, shared and exclusive Member State competences, respectively. In doing so, this section outlines two legal options that allow for CETA's entry into force even after a Member State's government has refused to sign or ratify the agreement. 
These legally feasible avenues for the signing and conclusion of an EU trade agreement - despite a Member States' rejection of its ratification however, should be understood as a last resort to safeguard the effectiveness and integrity of EU CCP formulation in context of broad general support for the conclusion of the treaty.

\subsection{CETA 'Wallonaise' classique: Rejection of a mixed agreement by a Member State parliament}

The conclusion of CETA as a mixed agreement requires that the treaty will be subjected to the vote of national and, in some EU Member States, regional parliaments. The mere fact that a national parliament rejects CETA, however, does not have any direct legal effect on the signature, provisional application or ratification of the agreement. Under international law, the rejection of a treaty's signature or its ratification requires a written executive notification in conformity with the provisions of the treaty. ${ }^{49}$ Hence, under international law, it is the Member State governments' prerogative to decide if, and to what extent, a negative parliamentary vote ought to be respected. National constitutional law may entail national legal obligations to that extent. Under both international and European law, however, it is the decision adopted by a national government that gives legal effect.

\subsection{CETA 'Wallonaise' avantgarde: Rejection of A MiXed AGREEMENT By a Member State government}

Advocate General Sharpston's enquiry, to be precise, concerns the legal implications of an executive rejection of a mixed agreement. In other words: Can CETA enter into force even if one or several Member State governments refuse to sign or ratify the agreement?

The procedures governing an agreement's entry into force are specified by international law. According to Article 24 (1) VCLT '[a] treaty enters into force in such a manner and upon such a date as it may provide or as the negotiating States may agree'. CETA Article 30. 7 (1) stipulates that '[t]he Parties shall approve this Agreement in accordance with their respective internal requirements and procedures'. The second paragraph of the same article prescribes that ' $[t]$ he Agreement shall enter into force on the first day of the second month following the date the Parties exchange written notifications certifying that they have completed their respective internal

49 Art. 65(1) and Art. 67(2) VCLT. 
requirements and procedures or on such other date as the Parties may agree' (emphasis added). ${ }^{50}$

The wording of Article 30.7 (1), (2) CETA, and, in particular, the unequivocal reference to each party's internal (constitutional) ratification procedures renders the entry into force of CETA contingent upon the exchange of written notifications by all contracting parties. As a result, CETA may only enter into force after Canada, the EU and all Member States have signed and ratified the agreement. By inference, the lack of one party's signature or ratification instrument may prevent CETA's entry into force. These established legal modalities have led some legal scholars to believe that an individual Member State can veto the Union's signature and conclusion of a mixed agreement. ${ }^{51}$

This line of reasoning, however, presumes that Member States enjoy the prerogative to reject mixed agreements in their entirety. Yet, the concept of exclusivity as enshrined in Article 2 (1) TFEU precludes independent internal as well as external Member State action. Member States are hence prevented from concluding international agreements with third parties in areas that fall under EU $a$ priori and implied exclusive competence. By inference, we argue that exclusivity also prevents Member States from vetoing the application of those areas of a mixed agreement that fall under EU exclusive powers in their territory. Member States can only reject the signature and conclusion of a mixed agreement for the parts that fall under exclusive national competences as well as shared competences that the EU has chosen not to exercise. Areas of shared competences, in which the Union has adopted internal EU rules, however, remain outside the Member States' external legislative prerogatives. In accordance with this conclusion, there are at least two scenarios that allow for the entry into force of CETA irrespective of a Member States' refusal to sign or ratify.

\subsubsection{The 'Inclusive' Scenario}

Legally speaking, the Commission proposals for the signature, provisional application and conclusion of CETA can be adopted by QMV in the Council..$^{52}$ As such, a dissenting Member State could be overruled by the Council and is then bound by the decision. Article 30.7 (1) (2) CETA requires, however, that each contracting party approves the treaty by signature and notifying ratification.

\footnotetext{
Art. 30.7 (2) CETA.

See for instance, Weiß, supra n. 14, at 27 or Heliskoski, supra n. 15, at 92 f.

The Council Decisions on the signature and provisional application of CETA ) indicate Art. 43(2), Art. 91, Art. 100(2), Art. 153(2), Art. 192(1) and the first subpara. of Art. 207(4), in conjunction with Art. 218(5) TFEU as legal bases. Accordingly, CETA can be concluded by QMV (after consulting the Economic and Social Committee and the Committee of the Regions (Arts 153 (2) and 191 (1) TFEU).
} 
One option to oblige a dissenting Member State to act upon a Council decision taken is the invocation of the principle of sincere cooperation that is enshrined in Article 4 (3) TEU. Accordingly, '[t]he Member States shall take any appropriate measure, general or particular, to ensure fulfilment of the obligations arising out of the Treaties or resulting from the acts of the institutions of the Union'. Moreover, the third paragraph of the article stipulates that the Member States 'shall facilitate the achievement of the Union's tasks and refrain from any measure which could jeopardise the attainment of the Union's objectives [emphasis added]'. As we have argued above, exclusivity prohibits (external) Member State action. If the Council decides to sign and conclude CETA (by QMV), a unilateral Member State measure that prevents the entry into force of those areas of the agreement that fall under exclusive EU competences therefore jeopardizes the attainment of Union objectives. As a result, Article 4 (3) TEU prescribes a duty for Member States to fulfil their obligations resulting from the decisions of the Council: they are bound to sign and ratify the parts of a mixed agreement that fall under EU a priori and implied exclusive competence.

The decision not to apply any provisions that remain under external Member State competences is a legislative choice of each Member State's government. In practice, a dissenting Member State could, for instance, formulate a reservation upon signing or ratifying the 'EU-exclusive' parts of the agreement that specifies the provisions that will not apply on its territory (Article 19 VCLT). CETA can, in this scenario, enter into force in accordance with the procedures laid down in the first and second paragraph of Article 30.7 CETA.

\subsubsection{The 'Exclusive' Scenario}

In the alternative, the EU has the option to exclude a Member State that refuses to sign or ratify CETA as contracting party. Confronted with such a situation, CETA can be 're-proposed' as an 'incomplete mixed agreement' that includes all other Member States, as well as the Union and Canada, as independent treaty parties. ${ }^{53}$ The dissenting Member State would, irrespective from being excluded as an independent contracting party, be bound by the areas of the agreement that fall under EU external competences. All areas that fall under external Member State competence would, in turn, not apply in the territory of that respective Member State. Similar to the 'inclusive' scenario, such an approach builds on the presumption that the necessary Council decision on the signature and conclusion of the agreement can be taken by QMV, so that the dissenting Member State cannot veto the treaty in the Council and is then bound by the treaty.

53 C.f. Gulliaume van der Loo \& Ramses Wessel, The Non-Ratification of Mixed Agreements: Legal Consequences and Solutions, 54 CMLR 735-770 (2017). 
In light of the Court's conclusion in Opinion 2/15, the EU might, according to this scenario, similarly choose to limit the content of CETA - as well as its future agreements - to provisions falling under EU exclusive competences in order to conclude them as 'EU-only' agreements. The Court's confirmation of the broad scope of the CCP post-Lisbon in Opinion 2/15 may hence significantly reduce the risk of national non-ratification. The following section provides an overview of the Court's conclusions in Opinion 2/15 and outlines the main implications for future EU commercial treaty-making practice.

\section{OPINION 2/15 AND THE FUTURE OF EU COMMON COMMER CIAL POLICY OR THE END OF MIXITY AS WE KNOW IT?}

On 16 May 2017, with its decision in Opinion 2/15 on the Union's competence to conclude FTA with Singapore (EUSFTA), the Court dropped a bombshell. ${ }^{54}$ The Court's ruling is set to significantly simplify the EU's economic relations with third countries. If the Commission, the Council and the Member States had demanded clarity as to which institutions may legitimately pursue the Union's external action objectives in its commercial relations: clarity is what they earned. The decision has the strong potential to facilitate an 'EU-only' signing and conclusion of future EU trade agreements considerably. At the same time, as we argue below, the Court's reasoning entails a number of contradictory elements that may add confusion over the legal parameters of post-Lisbon EU external relations conduct.

Given the broad and deep material coverage of the EUSFTA, the decision will serve as a precedent for the conclusion of the vast majority of future EU trade and investment agreements. The Court provides permissive guidelines as to how the EU Member States' lengthy parallel ratification procedures required by 'mixity' can be avoided in the design of future EU FTAs. By the same token, the CJEU thereby provides credible legal benchmarks that may inform the political discourse within and among the Member States with a view to safeguarding the effectiveness of the $\mathrm{CCP}$ and the credibility of the EU as an international actor in economic affairs.

The Court's decision in Opinion 2/15 stands in context of a number of pertinent CJEU decisions, in which the Court provided answers to some of the questions at stake. Overall, Opinion 2/15 further confirms the 2009 Lisbon Treaty reform of the CCP provisions and continues to walk on the path it had chosen in its post-Lisbon judgments. In this spirit, the Court reaffirms that 'the FEU Treaty differs appreciably from the EC Treaty previously in force, in that it includes new aspects of contemporary international trade in that policy. The extension of the

$\overline{54 \quad \text { Opinion }} 2 / 15$, supra n. 5. 
field of the [CCP] by the FEU Treaty constitutes a significant development of primary EU law'. ${ }^{5}$

In the following subsections, we outline the core case law, which sets out the legal reasoning that the Court has advanced in prior disputes. Subsequently, we provide a brief overview and discussion of the Court's main findings in Opinion 2/15.

\subsection{Case law of the court of Justice of the european union}

Prior to the entry into force of the Treaty of Lisbon, the Court emphasized the mixed nature of contemporary trade agreements. In its famous Opinion 1/94, the Court clarified that the European Community lacked the exclusive powers necessary for an 'EC-only' conclusion of the agreements that resulted from the Uruguay Round of multilateral trade negotiations, in general, and the General Agreements on Trade in Services (GATS) and Trade Related Aspects of Intellectual Property (TRIP), in particular. ${ }^{56}$ Moreover, the Court held that without the internal exercise of shared competence, e.g. in the area of trade related intellectual property rights protection, external Community action in that area could not be deemed exclusive by implication. In absence of an ERTA-effect, the Court considered both the Community and the Member States competent to conclude the WTO agreements in areas of shared competences. The 2009 Treaty of Lisbon, however, expanded the exclusive scope of CCP considerably by adding these two policy areas as well as FDI to the realm of CCP exclusivity. ${ }^{57}$

Two recent CJEU judgments have confirmed the extended scope of the CCP post-Lisbon and may give a first indication of how far the CJEU may go in its interpretation of Opinion 2/15. In Daiichi Sankyo, the Court placed the entire TRIPs agreement under the CCP. ${ }^{58}$ In Commission v. Council (Conditional Access Convention) the Court, in application of its gravity theory, held that Article 207 TFEU is the sole and correct legal basis of a treaty if the 'main purpose' of an international agreement is the external harmonization of EU norms that intend 'to promote, facilitate or govern trade' and has 'direct and immediate effects on trade'. 59 'Incidental' internal harmonization (of trade in services in this case) did not require reference to another legal basis, according to the Court. The decisions thus consolidate EU exclusivity of trade

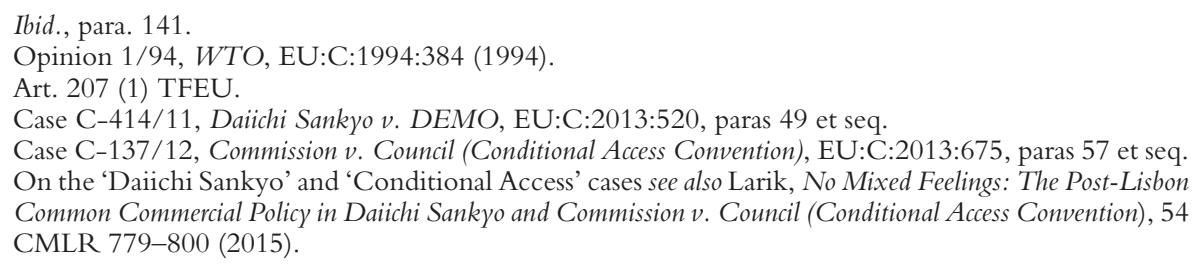


related policies and significantly reduce the potential for 'mixity' of EU trade and investment agreements in the future.

\subsection{THE OPINION OF THE COURT IN AVIS $2 / 15$}

With the exception of provisions relating to portfolio investment and the contentious ISDS mechanism, the Court now held that all components of the agreement can be concluded by the EU alone and without the approval of the Member States in their own right. ${ }^{60}$ In December 2016, Advocate General Eleonor Sharpston had advanced a considerably more restrictive reading of the EUSFTA in light of the EU treaties. In her view, EUSFTA provisions governing non-commercial aspects of intellectual property rights, certain transport services, portfolio investment, as well as the agreement's sustainable development provisions (labour rights; environmental protection) made for competences shared with the Member States. According to the AG, moreover, a single provision obliging the Member States to terminate their bilateral investment treaties with Singapore upon entry into force made for an MS exclusive competence. ${ }^{61}$

The key to understanding the Court's conclusions and its ability to clear the way for effective and efficient Union external economic action derives from an examination of the applicable standards of analysis and respective benchmarks. ${ }^{62}$ The Court, we find, used all the discretion available to it to produce a 'middle way' result with a view to enabling more effective, efficient, and legitimate governance of the Union's external economic relations. However, as we argue below, it appears that the coherence of the Court's legal reasoning, in some instances, has fallen victim to the purposes this decision seemingly attempts to advance.

First, in comparison to AG Sharpston's legal view, the Court applies a more inclusive 'aim and content' test to the EUSFTA in light of CCP Article 207 TFEU, which enables it to subsume EUSFTA content under the said provision in a more 'generous' manner. More precisely, the Court advances a wider application of the 'immediate and direct effects on trade' criterion, which it had developed in its past jurisprudence. ${ }^{63}$ By the same token, the Court's reasoning embeds the CCP into the context of EU external action objectives and thus gives full effect to the Lisbon reform in this regard. The combination of these two contingencies led the Court to

Opinion 2/15, supra n. 5, para. 305 .

AG Sharpston, Opinion $2 / 15$, supra n. 16, para. 570.

David Kleimann, Reading Opinion 2/15: Standards of Analysis, the Court's Discretion, and the Legal View of the Advocate General, EUI Working Paper RSCAS 2017/23.

63 For an explanatory account see s. 2 of this article. See further Case C-414/11, Daiichi Sankyo, supra n. 58 para. 51; Case C-411/06, Commission v. Parliament and Council, supra n. 9, para. 71; Case C-347/03, Regione autonoma Friuli-Venezia Giulia and ERSA, EU:C:2005:285, para. 75. 
the rather historic conclusion that the EUSFTA provisions on labour rights and environmental protection fall under the EU exclusive competence attributed to the CCP. ${ }^{64}$ In Article 13.1(3) EUSFTA, notably, the parties 'recognise that it is inappropriate to encourage trade or investment by weakening or reducing the protections afforded in domestic labour and environment laws'. In view of the Court, the EUSFTA provisions - by setting out minimum standards to which the parties are committed in context of other multilateral agreements - reaffirm the parties' commitment not to lower the protections afforded to labour and the environment in order to gain a competitive commercial advantage. Such provisions, according to the Court, sufficiently affect trade among the parties to fall within the ambit of the $\mathrm{CCP}^{65}$

Secondly, the Court casts a significantly wider web for 'incidental' treaty content than the Advocate General. Incidental treaty components or provisions, according to the Court's jurisprudence, are subordinated to the agreement's predominant purpose (i.e. commerce within the meaning of the CCP Article 207 TFEU) if they are 'extremely limited in scope' and thus do not have the potential to affect the allocation of competences. ${ }^{66}$ In application of a markedly more generous understanding of what is 'extremely limited in scope', the Court dismisses the AG's findings that 'moral rights' and 'inland waterway transport' could make for autonomous EUSFTA components. ${ }^{67}$ The Court hence does not require reference to legal bases for which the Union shares competence with the Member States.

Third, the Court, if compared to the AG's opinion, advances a considerably more lenient interpretation of implied exclusive powers with respect to its ERTA case law, which results in a broader shelter for EUSFTA transport services commitments. As explained above, the EU may, according to the ERTA jurisprudence, obtain exclusive external powers if an area is covered to a large extent by common internal rules, which may be altered or affected by the conclusion of an international agreement (Article 3(2)(3) TFEU). While the Court confirms the validity of the transport services carve-out from the scope of the CCP (Article 207(5) TFEU), it found that exclusive EU powers for maritime, road and rail transport services could in fact be implied via Article 3 (2)(3) TFEU. Building on its reasoning in Green Network and Opinion 3/15, the Court adopted a permissive application of the ERTA test's 'largely covered' criterion: even if EU legislation leaves considerable legislative powers to the Member States, it may still be affected or even altered by the conclusion of an international agreement. ${ }^{68}$ Complete internal harmonization is

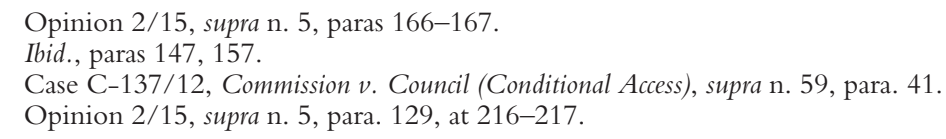


thus not required to trigger the ERTA effect. Indeed, the Court argued that any material overlap between EU internal and international commitments automatically 'must be regarded as capable of affecting or altering the scope of those common rules'. ${ }^{69}$

Fourth, the Court does not, in contrast to the AG, deem the termination of the Member States' bilateral investment treaties as a competence falling within exclusive national prerogatives. FDI liberalization and protection form part the EU's exclusive CCP competence. ${ }^{70}$ Accordingly, the EU superseded the Member States for FDI and may approve, by itself, a provision in an international agreement with a third party that replaces the Member States' prior bilateral FDI commitments with Singapore. Rather than engaging in the discussion of treaty termination provisions of the VCLT, the Court highlights that the EU's exclusive competence to terminate prior Member State FDI commitments with Singapore derives from to the doctrine of functional succession. ${ }^{71}$ Accordingly, "the European Union can succeed the Member States in their international commitments when the Member States have transferred to it $[\ldots]$ their competences relating to those commitments and it exercises those competences'. ${ }^{72}$ The Court left unaddressed, however, how such reasoning would bode with its finding that the Union shares competence with the Member States in respect to portfolio investment. ${ }^{73}$

Fifth, the Court's decision, in this instance, affirms AG Sharpston's finding on portfolio investment. The text of Article 207 TFEU explicitly refers to FDI only. ${ }^{74}$ In a prior judgment, the Court had clarified the conceptual difference between FDI and portfolio investment. FDI, according to the Court, presupposes lasting and direct economic links that enable the investor's effective participation in the management of a company. Conversely, portfolio investments merely transfer equity securities without implicating managerial control. ${ }^{75}$ In Opinion $2 / 15$, the Court therefore confirmed the textual interpretation of Article 207 TFEU that portfolio investment falls outside the scope of the CCP. Moreover, the Court - and AG Sharpston - dismissed the more artistic arguments of the Commission in favour of implied ERTA exclusivity

Case C-66/13, Green Network, paras 41-49 and Opinion 3/15, paras 126-128, both supra n.11.

Opinion 2/15, supra n. 5, para. 201.

Ibid., para. 87.

Ibid., para. 249

Case 21/72, International Fruit Company, EU:C:1972:115, para. 248

Opinion 2/15, supra n. 5. The Court addressed the issue of terminating the Member States pre-existing portfolio investment obligations with Singapore in less than two paras (255-256). The Court underlines that the termination of Member State BITs does not fall within exclusive Member State competence (para. 256). Yet, it does not explain how the EU may use its shared competence to terminate Member State BITs as regards portfolio investment.

$74 \quad$ Art. 207 (1) TFEU.

75 Case C-446/04, Test Claimants, EU:C:2006:774, paras 181-182. 
on the basis of a primary law provision, notably Article 63(1) TFEU. In doing so, the Court sets an important boundary for the ERTA doctrine: Triggering Article 3 (2)(3) TFEU presupposes the existence of internal EU legislation. Primary law provisions cannot be altered or affected by international EU agreements. ${ }^{76}$ Yet, the Court found that the EU and the Member States share the power to conclude non-direct investment agreements (Article 216 (1) TFEU). In addition, the Court points out that, 'as EU law currently stands', there is no internal legislation that endows the EU with the power to conclude international agreements in the field of portfolio investment. ${ }^{77}$ As a consequence, Article 3(2)(1) TFEU is currently not applicable, but may trigger exclusive competence once such legislation will have been adopted. In contrast to treaty amendments, a respective secondary legal act may be adopted by QMV, depending on the political will of the Member States.

Sixth, in a finding that is set to disturb the international investment arbitration community, the Court rules that the EUSFTA's ISDS mechanism falls within a competence shared between the EU and the Member States and thereby objects to AG Sharpston's reasoning. The AG had considered that the investor-state dispute settlement mechanism is accessory to the substantive investment protection obligations of the EUSFTA. ${ }^{78}$ According to the Court, however, a regime that removes disputes from the jurisdiction of domestic courts may not be regarded as ancillary (or: accessory) to such substantive obligations. ${ }^{79}$ Consequently, it 'cannot be established without the Member States' consent'. ${ }^{80}$ It is puzzling, to say the least, that the Court does not endeavour to ground this finding on an appropriate legal basis. Which legal basis, indeed, would confer a shared competence for the establishment of an ISDS regime?

Finally, and most surprisingly, the final paragraph of Opinion 2/15 does not fully answer the preliminary question posed by the Commission. The Court's response does set out the division and nature of competences between the EU and the Member States. But it does not answer the question whether 'the EU has the requisite competence to sign and conclude alone the Free Trade Agreement with Singapore'. AG Wahl and AG Sharpston, in respective recent opinions, considered that the EU has the requisite power to conclude agreements that fall under EU exclusive as well as shared powers. ${ }^{81}$ If an agreement contains content covered by exclusive and shared competence, the choice of procedure is subject to the political

Opinion 2/15, supra n. 5, para. 235.

Ibid., para. 236.

AG Sharpston, Opinion 2/15, supra n. 16, para. 523.

Opinion $2 / 15$, supra $\mathrm{n} .5$, para. 292.

Ibid., para. 292.

AG Wahl, Opinion 3/15, para. 119 and AG Sharpston, Opinion 2/15, para. 74, both supra n. 16. 
discretion of the EU institutions and, ultimately, the Council. In past commercial treaty-making practice, the EU institutions indeed opted for facultative mixity. However, facultative 'EU-only' agreements do exist, too. To name but one recent example: The Stabilisation and Association Agreement with Kosovo was concluded by the Union alone. ${ }^{82}$ The Court, however, appears to eliminate the possibility of facultative 'EU-only' treaty-making. In various paragraphs of its decision, it concludes that the EUSFTA 'cannot be approved by the EU alone' because it contains substantive areas that fall under shared competence. The Court therefore appears to equalize the effect of non-exclusive and non-existing EU external competence. What does this finding mean for existing facultative EU-only agreements? And what is the value inherent to shared external EU competence in the first place, if the Union cannot exercise such competence without the consent of the Member States in their own right?

The interested observer is therefore left with puzzling questions with regard to the future of facultative 'EU-only' treaty-making and the choice of a shared legal basis for the ISDS mechanism. Despite providing for much needed clarity as to the scope of the CCP in light of a 'new generation' of EU trade and investment agreements, Opinion 2/15 therefore preliminarily adds new questions over the legal parameters applying to the substance and process of EU trade and investment treaty-making. ${ }^{83}$

\section{CONCLUSIONS AND PROSPECTS: 'EU COMMON COMMERCIAL POLICY 2020'}

The 'Wallonian Saga' has - in a brutal manner - laid bare a twofold structural weakness of the European Union as an external actor. It is when the Union includes the Member States as independent contractors in the process of international treatymaking that the Achilles heel of European external action is fully exposed to attempts of political blackmail, rent-seeking, and self-interested opposition of small political fractions.

Europe's first weakness is one of democratic representation. The fact that a constituency of 3.5 million inhabitants is able to credibly threaten to bloc the signature of a treaty otherwise supported by the political representatives of 500 million EU citizens has reinforced already existing incentives for political paralysis of EU multilevel economic governance. The current form of 'mixed' treaty-making

\footnotetext{
82 Stabilisation and Association Agreement Between the European Union and the European Atomic Energy Community, of the One Part, and Kosovo, of the Other Part, 2015/0095 (NLE).

83 See also David Kleimann \& Gesa Kübek, The Singapore Opinion or the End of Mixity as We Know It, VerfBlog, http://verfassungsblog.de/the-singapore-opinion-or-the-end-of-mixity-as-we-know-it/ (accessed 23 June 2017).
} 
puts the fate of the European Union as an international actor into the hands of individual Members States or even regional governments rather than European Union citizens and the Union's legitimate political institutions.

Europe's second weakness is mirrored in the results that stem from such an inward-oriented notion of the European project and its political process: the Union increasingly suffers from a creeping ineffectiveness of its policy formulation process and paralysis of its multilevel governance polity, a loss of its credibility as an international actor, and policy outcomes that are distorted and rendered inefficient as private or public rent-seekers are given overly generous institutional access or power in the decision-making process. The EU, in its current mode of governance, will remain inapt to tackle the vast amount of economic and political challenges that it is confronted with in the early years of the twenty-first century. Democratic governance of EU external trade and investment policy, we argue, needs to sharply reduce the amount of veto players and render remaining veto rights commensurate to proportional democratic representation.

In the wake of the CETA crisis, some commentators were quick to advocate for 'EU-only' treaty-making as the appropriate alternative to 'mixity' in order to mend the second category of problems we outlined above. 'EU-only' agreements, indeed, would do away with the lengthy parallel ratification procedures at the Member State level and subject national democratic deliberations and decisions on the approval of EU external treaties to voting in the Council. As we have demonstrated in this article, however, treaty-making in the 'EU-only' procedure is, in the first instance, not a question of political preference, but a question of legal competence. It is the exact delineation of EU exclusive competences - codified in EU primary law and mirrored in constantly evolving EU secondary legislation - that determines whether the content of a treaty mandates 'EU-only' conclusion, or not.

With its decision in Opinion 2/15, the Court finally ended the legal uncertainty over EU trade and investment competence and provided authoritative guidelines to the policy-makers responsible for the design of preferential trade agreements. Opinion 2/15 confirms the tectonic shifts of competence that the Lisbon Treaty has brought about in the area of EU CCP. International treaty components governing trade in goods, services, commercial aspects of intellectual property, government procurement, competition policy, FDI admission and protection, transport services, e-commerce, and sustainable development provisions related to trade may be concluded by the EU without the participation of the Member States in their own right. As such, broad 'EU-only' economic agreements are now on the verge of becoming the new normal of EU external economic action, if such agreements were to exclude portfolio and ISDS and conclude such components separately as mixed agreements. These conclusions, admittedly, cast dark clouds over the future of the EU investment policy and, at the very least, the 
Commission's endeavour to reform the current bilateral investment treaty (BIT) system by means of a multilateral investment court (MIC). In this area, the Court places the Member States in the driver's seat. The Court's decision, nonetheless, places considerable pressure on the Member States to end the legal-political combat with the Commission over their involvement. With respect to portfolio investment, they may, eventually, wish to hand over exclusive external competence over the last bastions of shared competence via the legal avenue of Article 3(2)(1) TFEU. Moreover, should the Member States eventually come to the conclusion that they ought to advance a sensible reform of their old BIT regime, it is now up to national governments to take ownership and explain and sell the proposed Investment Court System to their domestic constituencies.

Overall, Opinion 2/15 therefore created the conditions for more effective, efficient, and politically legitimate EU external economic action. Although it placed a good amount of investment related homework on the desks of the Member States, the Court has done no less than giving a clear mandate to the institutions of the EU. A shift to 'EU-only' treaty conclusion of the exclusive trade and FDI parts of contemporary trade and investment agreements would indeed address the issues associated with European 'vetocracy' by reducing the amount of veto-players to no more than two: A blocking minority in the Council and a simple majority of Members in the EP.

Such a significant change of formal institutional practice, however, must not come at the expense of democratic accountability and representation. To the contrary, EU 2020 institutional practice needs to strengthen democratic governance of EU external trade and investment policy and reconnect to citizens' concerns over economic policies in a representative, visible, and functional manner.

The achievement of this objective, however, requires a considerable rethink, adaptation, and a sense of ownership of national parliaments regarding the economic policy-making process in the EU. In pre-Lisbon institutional practice, national parliaments often only engaged in the political process long time after a respective mixed agreement was signed by national governments and, essentially, rubberstamped agreements that were put before them for ratification. The run-up to the CETA signature has, somewhat ironically, shown early signs of the necessary and desirable shift of Member States' parliaments political engagement to the phase of the process where it is most needed for EU-only treaty-making. Prior to the signing of CETA, indeed, national parliaments have now made more extensive use of their constitutionally guaranteed role in national decision-making processes in a visible fashion. In context of 'EU-only' agreements, national parliamentary deliberation, scrutiny, and control of executive decisions ought to shift to the (pre-)negotiation stage of the treaty-making process in order to endow QMV Council decisions on the signature and provisional application of EU economic agreements with democratic 
legitimacy. Vertical inter-parliamentary cooperation can help to build trust in EU commercial policy making. The EP INTA committee, for instance, is frequently informed about on-going policy and negotiation developments, holds similar information rights to those of the Council, has built an intra-institutional infrastructure for an efficient division of labour, and has greatly improved its informational capacity over the last years. The development of vertical - formal or informal - links between the economic affairs committees of national parliaments and the INTA committee in the EP can facilitate issue specific problem-solving, build mutual trust, and function as an early warning system in regard of potential political or technical roadblocks.

Beyond the change of national institutional practice, secondly 'EU-only' treatymaking must go hand in hand with a notional and practical elevation of the EP, in addition to its acquisition of information, control, and veto-rights via the Lisbon Treaty of 2009. Addressing a long-standing deficiency, public perception of the EP as a significant governing institution ought to be enhanced and fostered. National electoral reforms that do away with party lists and allow for direct elections of Members of the European Parliament (MEP) in regional districts of the Member States can contribute to the achievement of this objective. Moreover, the central role of the EP as the democratic institution that effectively controls EU external economic policy making should be reinforced by a further strengthening of the EP's technical, research, and staff capacity in regard of EU trade and investment policy matters.

Finally, Member States governments and the EP ought to actively engage in restoring the public trust in and political support for the European Commission, which is functionally necessary for it to continue to serve as the agent of the Council and the EP in negotiating EU external economic agreements. Since the inception of Transatlantic Trade and Investment Partnership negotiations, the Commission has become the main target of post-factual political campaigns that aim at imposing a digital dominance of fundamental opposition and targeted misinformation of citizens rather than contributing to democratic deliberation processes or technical debates in a constructive manner. It is the Member States' governments as represented in the Council, the EP, and eventually the national parliaments that are equipped with the communication channels that are necessary to counter post-truth political campaigns and win public support for EU economic policies through political leadership.

Political change towards an institutional practice that affirms the Union's multilevel governance structures; that buys into the legally viable European democratic process; and that builds on the design of EU economic agreements can, in our view, remedy the two main structural weaknesses that the recent CETA episode has exposed. Our notion of the EU CCP governance in 2020, as outlined above, would render EU external treaty-making more democratic, more effective, more efficient, and more reliable. 
